慶應義塾大学学術情報リポジトリ

Keio Associated Repository of Academic resouces

\begin{tabular}{|c|l|}
\hline Title & Effect of substituents on the reaction of aromatic primary amines with fluorescamine \\
\hline Sub Title & \\
\hline Author & $\begin{array}{l}\text { 中村, 洋(Nakamura, Hiroshi) } \\
\text { 高山, 真弓( Takayama, Mayumi) } \\
\text { 田村, 善蔵( Tamura, Zenzo) } \\
\text { 与田, 玲子( Yoda, Reiko) } \\
\text { 山本, 有一( Yamamoto, Yuichi) }\end{array}$ \\
\hline Publisher & 共立薬科大学 \\
\hline Publication year & 1982 \\
\hline Jtitle & $\begin{array}{l}\text { 共立薬科大学研究年報 (The annual report of the Kyoritsu College of } \\
\text { Pharmacy). No.27 (1982.),p.56- 56 }\end{array}$ \\
\hline JaLC DOI & \\
\hline Abstract & \\
\hline Notes & 抄録 \\
\hline Genre & Technical Report \\
\hline URL & https://koara.lib.keio.ac.jp/xoonips/modules/xoonips/detail.php?koara_id=AN00062898-0000002 \\
\hline $7-0056$
\end{tabular}

慶應義塾大学学術情報リポジトリ(KOARA)に掲載されているコンテンツの著作権は、それぞれの著作者、学会または出版社/発行者に帰属し、その権利は著作権法によって 保護されています。引用にあたっては、著作権法を遵守してご利用ください。

The copyrights of content available on the KeiO Associated Repository of Academic resources (KOARA) belong to the respective authors, academic societies, or publishers/issuers, and these rights are protected by the Japanese Copyright Act. When quoting the content, please follow the Japanese copyright act. 


\title{
EFFECT OF SUBSTITUENTS ON THE REACTION OF AROMATIC PRIMARY AMINES WITH FLUORESCAMINE*
}

\author{
Hiroshi Nakamura, Mayumi Takayama, Zenzo Tamura \\ Reiko Yoda and Yuichi Yamamoto \\ 中村 洋, 高山真弓, 田村善蔵, 与田玲子, 山本有一
}

The effects of substituent on the reactivity of the monosubstituted anilines with fluorescamine (FLA) and the fluorescent properties of the reaction products (FI) were investigated. Generally, the substituent at o-position markedly inhibited the reactivity of the amino group (ortho-effect). While the electron-donating substituent seemed to be favorable for the formation of FI, the electron-attracting one seemed to lower reactivity of the amino group. However, the presence of the latter substituent led to the enhanced fluorescence of FI. The highly significant correlation was observed between the wavelengths $(\mathrm{nm})$ of the emission maxima $\left(\lambda_{\mathrm{em}}\right)$ and the Hammett's substituent constants $\sigma$.

* 本報告は Anal. Letters 15 (1982) A7 657-680 に発表. 